Sirman Ya. V., Savytskyi I. V. Analysis interconnection level index marker by endothelial NOS, hypoxia and dysfunction in the pathogenesis of experimental diabetic retinopathy. Journal of Education, Health and Sport. 2020;10(3):302-311. eISSN 2391-8306. DOI http://dx.doi.org/10.12775/JEHS.2020.10.03.032

https://apcz.umk.pl/czasopisma/index.php/JEHS/article/view/JEHS.2020.10.03.032

https://zenodo.org/record/4526332

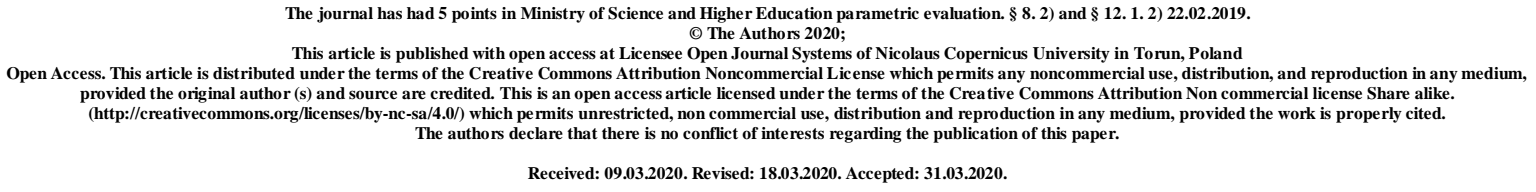

UDC: 616-06: 616-092.9

\title{
ANALYSIS INTERCONNECTION LEVEL INDEX MARKER BY ENDOTHELIAL NOS, HYPOXIA AND DYSFUNCTION IN THE PATHOGENESIS OF EXPERIMENTAL DIABETIC RETINOPATHY
}

\author{
Ya. V. Sirman ${ }^{1}$, I. V. Savytskyi² \\ ${ }^{1}$ SE "Ukrainian Research Institute of Transport Medicine of the Ministry of Health of \\ Ukraine" \\ ${ }^{2}$ Odessa International Medical University
}

Sirman Yana Vadymivna, Candidate of Medical Sciences, Senior Researcher, Laboratory of Occupational Pathology, SE "Ukrainian Research Institute of Transport Medicine of the Ministry of Health of Ukraine"; http://orcid.org/0000-0002-9754-2564; yanasirman@ gmail.com

Savitsky Ivan Volodymyrovych, Doctor of Medical Sciences, Professor, Head of the Department of Medical and Biological Sciences of Odessa International Medical University; https://orcid.org/00000002-5841-9993; farmakod@ukr.net

For correspondence: Savitsky Ivan Volodymyrovych, 65039, Odessa, Fontanska doroha 4-a, kv.29, tel. +38050-381-21-83, e-mail-farmakod@ukr.net

\section{Abstract}

The aim of the study was to analyze changes in erythrocyte diphosphoglycerate levels and Willebrand factor in the development of hypoxia and endothelial dysfunction in experimental diabetic retinopathy. The study was performed on white Wistar rats weighing 180-200 g. Our results indicate the development of hypoxia on the $30^{\text {th }}$ day of development of experimental diabetic retinopathy with subsequent progression of pathological changes on the $60^{\text {th }}$ and $180^{\text {th }}$ day of the study, as evidenced by the decrease level of 2,3 diphosphoglycerate of erythrocytes in the $2^{\text {nd }}$ group $(\mathrm{p}<0,001)$. The most pronounced increase in the studied 
marker of hypoxia was detected in the $3^{\text {rd }}$ stage of the experiment $(\mathrm{p}<0,001)$. As a result of our study, a violation of the structural and functional state of the endothelium in experimental diabetic retinopathy was proved, as evidenced by an increase in the level of Willeband factor in group 2 ( $\mathrm{p}<0.001)$, most pronounced in stage 3 . The most pronounced increase in the level of Willebrand factor was detected in the $3^{\text {rd }}$ stage of the experiment $(\mathrm{p}<0.001)$. Analyzing the data obtained, we can say that there is a relationship between the development of hypoxia and endothelial dysfunction in the pathogenesis of experimental diabetic retinopathy.

Key words: experimental diabetic retinopathy; hypoxia; endothelial dysfunction; 2,3 erythrocyte diphosphoglycerate; Willebrand factor; correction; metformin; aflibercept; L-arginine; citicoline; L-carnitine; bromfenac.

\section{Introduction}

As noted, diabetes is characterized by a number of complications that can lead to disability, complete disability and even premature death. According to the study Cost of Diabetes in Europe-Type 2 (CODE-2) in patients with diabetes mellitus, whose average age was 67 years, complications were observed in 59\% of patients, of whom $23 \%$ had 2 and 3\% 3 complications type 2 diabetes. Mortality from diabetes reduces the lives of patients by 12 14 years due to vascular accidents, which were recorded in $75-80 \%$ of cases. In the developed world, mortality from diabetes ranks 3-4 in the overall structure and is the cause of decreased vision and blindness in adults [1].

No more than $1-4 \%$ of patients die directly from diabetes, namely diabetic coma. The main cause of death in this pathology are vascular complications: nephropathy, neuropathy, retinopathy, amputation, stroke, cardiovascular disease, in the pathogenesis of which a key swarm is played by hyperglycemia and related metabolic effects [2]. Complications that occur in the late stages of diabetes are divided into micro- and macroangiopathy, the formation of which in diabetes determines the prognosis for quality and life expectancy of patients, so we can say that "diabetes begins as a metabolic disease" and ends as a vascular catastrophe» [3].

It should be noted that even with the compensation of carbohydrate metabolism, the development of DR continues, so hyperglycemia is not the only factor in the development of retinopathy in diabetes. Other important reasons include the role of hypertension, vascular tone disorders and the development of macular edema [4-8]. To date, the key role of endothelial dysfunction in the occurrence and progression of DR has been proven $[9,10]$. It was determined that the initial morphological signs of the studied pathological condition are endothelial cell proliferation, thinning of the basement membrane and loss of pericytes, which 
in turn leads to aneurysms and violation of vascular capillary diameter and hemodynamics $[11,12]$.

It has been proven that endothelial cells are the first to "take the blow" of hyperglycemia, glucose toxicity and dyslipidemia and under its influence begin to synthesize atherogenic factors $[9,14]$. There is an increase in the permeability of the vessel wall and violation of their elasticity, which leads to hemorrhages and exudates. Transcapillary transport is disrupted, which in turn leads to retinal ischemia [14].

The aim of the study: analysis of changes in erythrocyte diphosphoglycerate levels and Willebrand factor in the development of hypoxia and endothelial dysfunction in experimental diabetic retinopathy.

Materials and methods. The study was performed on white Wistar rats weighing 180-200 g. According to the tasks, the animals were divided into 2 groups:

Group 1 - 60 intact animals;

Group 2 - 60 animals, which simulated diabetic retinopathy without further correction.

Type 2 diabetes mellitus and diabetic retinopathy were modeled by intraperitoneal administration of streptozotocin (Sigma, USA) dissolved in $0.1 \mathrm{M}$ citrate buffer with a $\mathrm{pH}$ of 4.5 [15]. The dose of streptozotocin $55 \mathrm{mg} / \mathrm{kg}$ body weight was divided into two injections. The introduction of streptozotocin was preceded by a high-fat diet for 28 days [16].

Animals were removed from the experiment by decapitation under light ether anesthesia in accordance with the "Rules for performing work using experimental animals", approved by the Order of the Ministry of Health of Ukraine № 249 from 01.03.2012 and the Law of Ukraine № 3447-IV "On protection of animals from cruel treatment" (as amended from 15.12.2009 and from 16.10.2012).

Blood was taken from the retroorbital venous plexus, which lies in orbit behind the eyeball. The puncture was performed in a circular motion with a glass pipette with an extended capillary, the tip of which is ground at an angle of $45^{\circ}$. The conjunctival sac was punctured in the medial corner of the eye between the eyeball and the orbit. After puncture, the pipette was inserted to a depth of 2-4 mm behind the eyeball. Control of entry into the venous plexus - filling the pipette capillary with blood (Dyakonov AV, Khrikina IS, Hegai AA, etc., 2013).

The level of 2,3 erythrocyte diphosphoglycerate was determined by spectrophotometric method. The level of Willebrand factor was determined by enzyme-linked immunosorbent assay over ristocytin time.

Statistical processing of the obtained results 
To detect changes in the studied indicators between different groups and at different stages, we used parametric statistical methods, which are based on the operation of the parameters of statistical distribution (mean and variance).

The methods used are designed for normally distributed data, so we checked all data for normality using the criterion of asymmetry and excess EI Pustylnyk. According to this criterion, the distribution does not differ from normal if the calculated empirical values of asymmetry and excess do not exceed the critical, ie $A_{e m p}<A_{C r}, E_{e m p}<E_{c r}$, where $A_{e m p}$ and $E_{e m p}$ - calculated values of asymmetry and excess, and

$$
A_{c r}=3 \cdot \sqrt{\frac{6 \cdot(n-1)}{(n+1) \cdot(n+3)}}, E_{c r}=5 \cdot \sqrt{\frac{24 \cdot n \cdot(n-2) \cdot(n-3)}{(n+2)^{2} \cdot(n+3) \cdot(n+5)}},
$$

respectively, their critical values [17].

All the data we consider were normally distributed, so you can compare the average values of the samples in pairs. Note that in subsequent comparisons, we perform comparisons in independent samples. These will be comparisons between different groups of animals or comparisons between the same group of animals (but since there is no correspondence between animals in the samples, they will also be independent).

Before comparing the averages of the two samples, it should be ascertained whether the variances are homogeneous. For this purpose it is necessary to carry out check for homoscedasticity (homogeneity of dispersions).

Statistical hypotheses will be as follows:

$\mathbf{H}_{0}$ : the variance in group 1 does not differ from the variance in group 2.

$\mathbf{H}_{1}$ : the variance in group 1 is greater than the variance in group 2 . The

hypotheses in the criterion are directed, so the criterion is one-sided. Hypothesis $\mathrm{H}_{0}$ is rejected when $F_{e m p}>F_{c r}$. This is evidenced by the $p$-value - the probability of error to reject the null hypothesis when it is correct. In various experiments, take $\mathrm{H}_{0}$ when $p$-value (set significance level), and reject $\mathrm{H}_{0}$ when $p$-value $<$. In all subsequent calculations, we chose a standard level of significance $=0.05$.

The comparison of the averages is performed using $t$ Student's-test. When comparing the average directed hypotheses will be as follows:

$\mathbf{H}_{\mathbf{0}}$ : the average of group 1 does not differ from the average of group 2.

$\mathbf{H}_{1}$ : the average of group 1 is greater than the average of group 2. 
To decide the absolute value of the calculated $t$ is compared with one-sided critical. If $\left|t_{e m p}\right|<t_{c r}$, the null hypothesis can not be rejected. Here it is similarly possible to draw a conclusion and on $p-$ value.

All tests will be performed in the statistical package PASW Statistics 18. We will use the t-test procedure for independent samples, which immediately compares variances and means.

In subsequent tests, we will note whether the average values differ. If they are different, you need to specify this difference. The results of the t-test give an answer about the equality or difference of the mean values, but they do not allow to accurately measure the difference between the mean values. Note that this difference is quite conditional. We will calculate this difference as a percentage, ie the percentage difference between the average values of the 1st and 2nd groups will be equal to $\left(\frac{-20.604}{104.79}\right) \cdot 100 \%=19.66 \%$.

Thus, we demonstrated a comparison of the mean values between different groups of animals.

\section{Results of the study and their discussion:}

Results of the study of the dynamics of 2,3-diphosphoglycerate levels of erythrocytes in the blood of animals simulated with diabetic retinopathy

Of great importance in the development of vascular complications are compensatory mechanisms of hypoxia associated with blood oxygen transport in tissue capillaries. This mechanism is to reduce the affinity of hemoglobin for oxygen (shift of the dissociation curve of oxyhemoglobin to the right) and is an effective remedy against secondary tissue hypoxia and does not require energy [18-21]. The main mechanism of adaptation to hypoxia is the path of anaerobic oxidation of glucose in erythrocytes and the growth of 2,3 diphosphoglycerate - an allosteric regulator of the affinity of hemoglobin for oxygen [22, 23]. Under physiological conditions, the activity of 2,3-DFG in humans is suppressed. An increase in its concentration is observed during hypoxia, a marker of which it acts in experimental studies [24]. Hypoxia is both an etiological factor and an integral part of the pathogenesis of endothelial dysfunction [25].

In the second group, in which rats were simulated pathological condition without correction, a significant - by $65.03 \%$ ( $\mathrm{p}<0.001)$ increase in the studied marker of hypoxia on 1st stage. At the 2nd stage of its level at $66.41 \%$ ( $\mathrm{p}<0.001)$ higher than the value of intact animals, and on the 3rd stage of the increasing content of 2.3 difosfohlitseratu red blood cells 
is increased even more - he at 70.22\% ( $\mathrm{P}<0.001)$ higher compared with data from rats of the 1st group. In the third stage, the rate is higher by $14.94 \%$ ( $\mathrm{p}<0.001)$ compared to the first, and $11.05 \%$ ( $p<0.05$ ) compared with the second stage, ie we can say that the duration of the development of DR without correction hypoxia progresses steadily.

Table 1. - Level 2.3 of erythrocyte diphosphoglycerate in the blood of experimental animals with simulated diabetic retinopathy and various methods of its correction in the $30^{\text {th }}$, $60^{\text {th }}$ and $60^{\text {th }} 180^{\text {th }}$ day $(\mathrm{M} \pm \mathrm{m}),(\mathrm{mmol} / \mathrm{ml})$

\begin{tabular}{|l|c|c|c|}
\hline $\begin{array}{c}\text { Stages of } \\
\text { Group }\end{array}$ & I stage & II stage & III stage \\
\hline 1 group & $1.21 \pm 0.02$ & $1.22 \pm 0.03$ & $1.22 \pm 0.03$ \\
\hline 2 group & $3,47 \pm 0.13$ & $3.63 \pm 0.15$ & $4.08 \pm 0.11$ \\
\hline
\end{tabular}

The results of the study of the dynamics of the level of Willebrand factor in the blood of experimental animals with simulated diabetic retinopathy at 30, 60 and 180 days (Table 2).

Table 2 - The level of Willebrand factor in the blood of experimental animals with simulated diabetic retinopathy on the 30th, 60th and 180th day $(\mathrm{M} \pm \mathrm{m}),(\%)$

\begin{tabular}{|l|c|c|c|}
\hline $\begin{array}{c}\text { Stages } \\
\text { Group }\end{array}$ & I stage & II stage & III stage \\
\hline 1 group & $84.2 \pm 1.28$ & $84.2 \pm 1.27$ & $84.2 \pm 0.95$ \\
\hline 2 group & $104.8 \pm 0.87$ & $108.9 \pm 1.15$ & $112.4 \pm 1.18$ \\
\hline
\end{tabular}

The increase in the concentration of Willebrand factor in the blood combined with experiments on rats with endotoxemia and mechanical damage to the inner wall of blood vessels, which was also proven in clinical trials [26-29]. Endotheliocytes synthesize Willebrand Factor, which is normal in blood plasma at physiological concentrations [29].

A significant role of the Willebrand factor is the function of the messenger in platelet aggregation and in vascular-platelet interaction at the stages of adhesion [30, 31]. During these reactions, PV acts as a mediator between platelets and subendothelial structures of the damaged vascular wall [32].

The Willebrand factor is formed with a small excess. Molecules that are not involved in the implementation of physiological functions accumulate in the intracellular organelles of endothelial cells - Weibel-Palade bodies. There they are subject to post-translational modification and multimerization and can be quickly mobilized [29]. 
PV has a high molecular weight and activates thrombosis. By promoting the attachment of platelet receptors to vascular collagen and fibronectin, it thereby enhances platelet aggregation and adhesion. Willebrand factor formation is exacerbated by endothelial damage or vasopressin. If we take into account that the secretion of vasopressin is enhanced during stress, we can conclude that due to the activation of the synthesis of Factor Willebrand in extreme conditions increases vascular thrombogenicity. It should be noted that PV also stabilizes the factor VIII molecule, prolonging its half-life and facilitating its transport to the site of hemostatic plug formation [33].

In the group in which diabetic retinopathy was simulated without further correction (group № 2) already at the 1st stage revealed an increase in the level of Willebrand factor by $19.66 \%$ compared with data from intact animals $(\mathrm{p}<0.001)$. In the second stage, PV was higher by $22.69 \%$ ( $\mathrm{p}<0.001$ ) compared with the data of the 1 st group and by $3.77 \%$ compared with the data of its group in the previous stage $(p<0.01)$. The results of the third stage confirm the progression of endothelial dysfunction: compared with the intact group, the level of Willebrand factor is higher by $25.09 \%$ ( $\mathrm{p}<0.001$ ). Analyzing the dynamics of PV in group №2, it was found that at the 3rd stage its level was higher by $6.76 \%(\mathrm{p}<0.001)$ compared to the first stage, and by $3.11 \%$ ( $\mathrm{p}<0.05$ ) compared to others.

\section{Conclusions:}

1. Our results indicate the development of hypoxia on the $30^{\text {th }}$ day of experimental diabetic retinopathy with subsequent progression of pathological changes on the $60^{\text {th }}$ and $180^{\text {th }}$ day of the study, as evidenced by a decrease in 2.3 levels of erythrocyte diphosphoglycerate in the 2nd group ( $\mathrm{p}<0.001)$.

2. The most pronounced increase in the studied marker of hypoxia was detected in the $3^{\text {rd }}$ stage of the experiment ( $\left.p<0,001\right)$.

3. As a result of our study, a violation of the structural and functional state of the endothelium in experimental diabetic retinopathy was proved, as evidenced by the increase in the level of Willeband factor in group 2 ( $\mathrm{p}<0.001)$, most pronounced in stage 3 .

4. The most pronounced increase in the level of Willebrand factor was detected in the $3^{\text {rd }}$ stage of the experiment ( $\left.\mathrm{p}<0,001\right)$.

5. Analyzing the data obtained, we can say that there is a relationship between the development of hypoxia and endothelial dysfunction in the pathogenesis of experimental diabetic retinopathy. 


\section{References}

1. Susla OB, Misula IR, Gozhenko AI. Strukturno-funkcional'ni zmini endoteliju i kal'cinoz sercevih klapaniv u pacijentiv iz hronichnoju hvoroboju nirok do provedennja dializu. Krovoobig ta gemostaz. 2011;3-4(33-34):64-68.

2. Pashkovs'ka NV, Pashkovs'kij VM. Cukrovij diabet i mozkovij insul't: suchasnij pogljad na problemu. Mizhnarodnij endokrinologichnij zhurnal. 2018;14(4):11-22.

3. Kuznecova AS, Gozhenko AI, Kuznecova ES, Shuhtin VV, Kuznecova EN, Kuznecov SG. Jendotelij. Fiziologija i patologija: monografija. Odessa: «Feniks», 2018. 284 s.

4. American Diabetes Association: Standarts of medical care in diabetes-2011// Diabetes care. - 2011. — Vol. 34, Suppl. I: S4-88.

5. Shestakova M.V., Shamhalova M. Sh. Sovremennyj podhod k profilaktike i lecheniju diabeticheskoj retinopatii: rezul'taty issledovanija DIRECT, 2009. Spravochnik poliklinicheskogo vracha. — 2009. - № 1. - S. 3-39.

6. Delano FA, Chen AY, Wu KI, et al. The autodigestion hypothesis and receptor cleavage in diabetes and hypertension // Drug Discov Today Dis Models. - 2011. — Vol. 8. - P. 37-46.

7. Wright AD; Dodson PM. Diabetic Retinopathy and Blockade of the Renin Angiotensin System: New Data from the DIRECT Study Programme // Eye. 2010. — Vol. 24. - P. 1-6.

8. Porta M, Maldari P, Mazzaglia F. New approaches to the treatment of diabetic retinopathy // Diabetes Obes Metab. — 2011. - Vol. 13. - P. 784-790.

9. Gavrilova N.A., Tishhenko O.E. Vlijanie sulodeksida na funkcional'noe sostojanie jendotelija u bol'nyh saharnym diabetom i diabeticheskoj retinopatiej // Saharnyj diabet. 2011. № 2. S. 66-68.

10. Astahov Ju.S., Shadrichev F.E., Lisochkina A.B. Diabeticheskaja retinopatija // Oftal'mologija - 2006. Klinicheskie rekomendacii / pod red. L.K. Moshetovoj, A.P. Nesterova, E.A. Egorova. M.: GJeOTAR-Media, 2006. S. 139-163.

11. Vorob'eva I.V., Gigineishvili D.N. Rol' disfunkcii jendotelija v patogeneze diabeticheskoj retinopatii u bol'nyh saharnym diabetom 2 tipa. Obzor. Oftal'mologija. 2012;9(3):9-13.

12. Kasatkina S. G., Kasatkin S. N. Znachenie disfunkcii jendotelija u bol'nyh saharnym diabetom 2-go tipa // Fundamental'nye issledovanija. —2011. — № 7 - S. 248252. 
13. Neroev V. V., Sarygina O. I., Levkina O. A. Rol' sosudistogo jendotelial'nogo faktora rosta v patogeneze diabeticheskoj retinopatii //Vestnik oftal'mologii. — 2009. — № 2. - S. 58-60.

14. Koledincev M.N., Verzin R.A. Rol' korrekcii sostojanija jendotelija i bazal'noj membrany sosudistoj stenki pri diabeticheskoj retinopatii// Jeffektivnaja farmakoterapija. Jendokrinologija.- 43/2015.-№5.

15. Pavlova ON Investigation of the dynamics of catalase activity in the blood serum of rats under mechanical action on the blood-ophthalmic barrier / ON Pavlova, ON Gulenko, RG Karimova, etc. // International research journal. - 2020. - № 5 (95) 1.-C.153-158.

16. Bykov IL The effect of L-carnitine on metabolic disorders in experimental deficiency of acyl-CoA dehydrogenases. Experimental and clinical pharmacology. 2004. Volume 67 - № 6. P.48-52.

17. Lupan IV, Avramenko OV, Akbash KS Computer statistical packages: a textbook. - 2nd type. - Kirovograd: "CODE" 2015. - 236 p.

18. Matvieienko Mariia, Baranova Nadiia, Boiko Olena, Arora Sukesh. (2020) Features of the Functional State of Red Blood Cells During Hypoxia in Patients with Polytrauma. World Science. 6(58), Vol.2.doi:10.31435/rsglobal_ws/30062020/7111

19. Rjabov G. A. Gipoksija kriticheskih sostojanij / G. A. Rjabov. - M.: Medicina, 1988. $-287 \mathrm{~s}$.

20. Xu F, et al. Effect of hypoxia and hyperoxia on cerebral blood flow, blood oxygenation, and oxidative metabolism. J Cereb Blood Flow Metab 2012;32(10):1909-1918. DOI: $10.1038 /$ jcbfm.2012.93

21. Jensen M L F, Vestergaard M B, Tønnesen P, Larsson H B W, Jennum Poul J. Cerebral blood flow, oxygen metabolism, and lactate during hypoxia in patients with obstructive sleep apnea. Sleep. - 2018. - V.41., Issue 3. P.1-10. https://doi.org/10.1093/sleep/zsy001

22. Derjugina A. V., Bojarinov G. A., Simutis I. S., Bojarinova L. V., Azov N. A. Morfologicheskie i metabolicheskie pokazateli jeritrocitov pri obrabotke ozonom jeritrocitnoj massy. GENERAL REANIMATOLOGY. 2018; 14(1): 40-49. DOI:10.15360/1813-97792018-1-40-49

23. Krylov V.N., Derjugina A.V., Simutis I.S., Bojarinov G.A., Senjurina A.I. Soderzhanie ATF i 2,3DFG v jeritrocitah pri konservacii i vozdejstvii ozona. Biomedicina. 2014; 2: 37-42. URL: http://scbmt.ru/mag/2014/2014-02.pdf\#page=39 
24. Sposob povyshenija naprjazhenija kisloroda $\mathrm{v}$ krovi pacientov $\mathrm{s}$ hronicheskoj serdechnoj nedostatochnost'ju. V. Kukes, A. Prokof'ev, A. Zhestovskaja , V. Smirnov, L. Pavlova, O. Goroshko, O. Checha. Vrach. 2015 №11. S.83-86

25. Loktionova, IL, Pokrovsky, MV, Ragulina, VA, Titareva, LV, Denisyuk, TA The state of vascular endothelial function in infectious pathology of various etiologies // Scientific Bulletin of BelSU . Ser. Medicine. Pharmacy. - 2012. - №4 (123), issue 17/1-C. 20-31.

26. Malaja LT, Korzh AN, Balkovaja LB. Zndotelial'naja disfunkcija pri patologii serdechno-sosudistoj sistemi. - H. : Torsing, 2000. - 432 s.

27. Mazaev AA, Najmushin JaA, Haspekova SG. Faktor Villebranda i rastvorim'ij Rselektin u bol'n'ïh s ostr'im koronarnim sindromom bez pod'-ema segmenta ST pri lechenii antagonistom glikoproteiov II"/IIIa zpifibatidom. Kardiologija. 2007;6:4-9.

28. Serik SA. Immunnovospalitel'naja aktivnost' pri ishemicheskoj bolezni serdca. Ukraïns'kij kardiologichnij zhurnal. 2002;1:40-45.

29. Polivoda SN, Cherepok AA. Faktor Villebranda kak marker jendotelial'noj disfunkcii u pacientov s zabolevanijami serdechno-sosudistoj sistemy. Ukraïns'kij revmatologichnij zhurnal. 2000;1:13-18.

30. Lutaj MI. Ateroskleroz: sovremenn'ïj vigljad na patogenez. Ukraïns'kij kardiologichnij zhurnal. 2004;1:22-34.

31. Lutaj MI, Golikova IP, Dejak SI. Vzaimosvjaz' faktora Villebranda s sosudistodvigatel'noj funkciej zndotelija u bol'n'ïh s raznoj stepen'ju v'irazhennosti ateroskleroza venechn'ïh arterij. Ukraïns'kij kardiologichnij zhurnal. 2003;6:13- 17.

32. Voznjuk LA, Pivtorak KV, Semenenko SI. Faktor Villebranda jak kriterij zapalennja i disfunkciï endoteliju u hvorih na ishemichnu hvorobu sercja. Visnik problem biologiï i medicini. 2012;1;2(92):39-42.

33. Porojskij SV, Voronkov AV, Tjurenkov IN, Bulycheva OS, Samojlova OS. Jendotelial'naja disfunkcija $\mathrm{v}$ hirurgii. Covremennyj vzgljad na problemu. Vestnik VOLGGMU. 2011;3;39:13-17. 